\title{
THE COMMON LAW MORTGAGE AND THE CONDITIONAL BOND
}

\author{
Jacob J. Rabinowitz †
}

The classical mortgage of the common law takes the form of an absolute conveyance of the mortgaged property, with a defeasance clause providing that upon payment of the mortgage debt on the due date the property is to revert back to the mortgagor. ${ }^{1}$ This form of mortgage goes back, at least, to the I2th century, and, contrary to the prevailing view, was certainly in general use by the middle of the $13^{\text {th }}$ century. ${ }^{2}$ Originally, the transaction would take the form of two separate instruments, one an absolute charter of feoffment, and the other

†B. S, 1929, Columbia University; M.A., I931, LL. B, 1937, New York University. Member of the New York Bar. On the legal staff of The Department of Investigation, City. of New York. Author: $A$ Note on the Jewish Execution in Medieval Germany, Jewish Soctal Studies, vol. V, No. 3; Evasions of the Usury Laws in the Middle Agcs, to be published in the Harvard Theological Review; The Brordeis Method in Constitutional Law, Bitzaron (a Hebrew publication), vol. V, No. 2.

1. 2 Pollock and Maitzand, History of English Law (2d ed. 1898) 122-123.

2. Hazeltine has traced it only as far back as 1230, to pl. 458 in Bracrow's Note Book. See his Gage of Land in Medieval England (1904) 17 HARv. L. REv. 549, 557, n. 1. Pollock AND MAITLAND, loc. cit. supra note 1 , apparently place its beginning after the 13th century, although in a note they say: "It is very possible that this form. of gage, the conditional feoffment, had been in use from an early time, but that textwriters found little to say of it; because it fell under the general doctrine of conditional gifts." But these great historians of English law apparently overlooked the fact that this type of mortgage underwent two distinct stages of development, and that the first stage, in which two instruments were used, reaches as far back as the time of Henry II. No. 509 in Madox, Formulare Anglicanum (temp. Henry II) clearly represents a transaction of this type. It is an agreement between mortgagor and mortgagee that within $2^{\mathrm{T}} / \mathrm{3}$ years from the date of the instrument the mortgagor or his brothers or nephew may redeem the property, and that upon their failure to do so the property is to remain to the mortgagee in accordance with his charter. "Et risi poterimus ad istud terminum terram illam emere, teneat praedictus Toma . . . sicut carta sun testatur. - . ." Obviously, two instruments, a charter of feoffment and an agreement of repurchase, were used in this transaction. What the writer cannot understand is that Pollock and Maitland cite this instrument as an instance of what they call the "Bractonian mortgage," under which a term of years was turned into a fee upon the mortgagor's failure to pay the mortgage debt. The above quotation from the instrument shows beyond any doubt that a charter of feoffment was delivered to the mortgagee, or perhaps, to a third party, simultaneously with, or prior to, the execution of that instrument.

3 Holdsworth, A History of Engrish LAw (3d ed. 1923) 130, referring to the classical English mortgage, says: "It gained in popularity from the I4th century onwards." And in note 3 he adds: "This fact can be illustrated from the forms of conveyance printed in Madox Form. In 1255 (No. 230) we have a mortgage of the older type made by a lease for fifteen years. In Edw. III's reign the custom seems to have been to employ two deeds. - . In $140 \mathrm{r}$ only one deed is used, and the condition is indorsed on the deed. : - Ig Hy. VI we get a mortgage in modern form." But the cases cited in note 3 infra, show that this type of mortgage was prevalent in the I3th century, and that the custom of employing two deeds goes well beyond the reign of Edw. III. Indeed, there is almost contemporary testimony to the prevalence of the classical English mortgage in the 13 th century. In Rye v. Tumby, 8 Edw. If, 36,38 , which was a case involving a mortgage in the form of two separate instruments, there is the following statement: "In past times men were often wont to make such covenants and conditions." 
providing for a defeasarce of the conveyance upon payment of the mortgage debt. ${ }^{3}$ Later on it became customary to include both, conveyance and defeasance, in the same instrument. In the earlier stage of the development of this form of mortgage the charter of feoffment and the instrument of defeasance were usually delivered to a third party, "in equal hand," to be turned over to the lender in case of non-payment of the mortgage debt on the due date, or to be returned to the borrower in case of payment. This last feature of the early development of the classical English mortgage has been entirely overlooked by writers on the subject, although it appears quite frequently in entries on the Close Rolls during the latter part of the reign of Henry III and during the reign of Edward $10^{5}$

The origin of this obviously artificial device, which does not correspond either to the true economic significance of the transaction or to the intention of the parties, has never been satisfactorily explained. Nor is the reason for it quite apparent. Why should a mortgage, given to secure a debt, take the form of an immediate and absolute conveyance of the mortgaged property, when what is intended is a forfeiture of the property to take effect in the future in the case of non-payment of the mortgage debt?

3. Mladox, Formulare (ca. 1248) No. 631 ; Calendar of The Close Rolls, 126r1264, pp. 310-311; 1264-1268, pp. 105, 385-386, 391-392, 525; 1272-1279, pp. 332, 413, $415,421,428$.

4. Il adox, Formulare (1401) No. 579. The defeasance is indorsed on the back of the charter of feoffment. In (1448) No. 589 the defeasance clause is on the face of the charter,as in our modern mortgage.

5. In all of the entries cited in nute 3 supro, from Close Rolls, 1261-1264 and $1264-126 \%$, as well as in those at pp. 421 and 428 of 1272-1279, the "equal hand" is specifically mentioned. In the three other entries there is no mention of a deposit with a third party, but this does not necessarily mean that there was no such deposit in these cases. Sce also Y. B. 21 \& 22 Edw. I, p. 222, and Rye v. Tumby, note 2 supra. In the former case, which was an action of novel disseisin, the defendant's answer is recorded as follows: "B came and said that he (Adam) could not have an action; for the reason that Adam had pledged the said tenements to him for $40 t$ to be paid on two certan days, riz., $20 £$ on such a day, and the other $20 £$ at such a day; and that, if he failed in payment at the days fixed, the land should remain to $B$ and his heirs in fee; and that in pursuance thereof he made a charter of fcoffment, which was deposited "ith an umpire, to be delivered to him to whom it ought to be delivered after the days were passed. . ."

Reference to a conditional conveyance, probably by way of security for a loan, in which the instruments were delivered to a third party, is also contained in the following cntry on the Pipe Rolls: "Prior de Kenillewurda debet c. s. pro habendo judicio de Flechamsteda secunclum cartas suas quas Templarii tenent." Pipe Roll Society Publ. v. 2 (x. s.), D. 128 (II9r). The treasury of the Templars was often used as the depositary, the "equal hand," in such conditional conveyances by way of security for loans. In the document cited above from Close Rolls, 1264-I 268, pp. 385-386, 391392, there is the following recital: "Carta vero fcoffamenti quam idem . . . habet de dicto . super dictis maneriis in equali manu de consensu partium ad Novum Templum Lond' liberetur." A similar recital is also contained in Close Rolls, 1261126. pp. 310-311. See also Calendar of the Charter Rolls, v. 1, pp. 72 (1228), 73 (1228), 438 (1255), and Calendar of The Plea Rolls of The Exchequer of The Jews, v. 3. $\mathrm{pp}$. 283-284, for references to deposits with the Templars of cash and documents in conditional transactions of various kinds. 
This strange form of the common law nortgage becomes still more puzzling when we compare its pattern with that of the conditional or penal bond and find a striking similarity between them. The conditional bond contains in itself the same logical twist as that involved in the common law mortgage. Instead of the conditional obligation it is intended to be, with the obligation emerging upon the happening of a certain contingency, it takes the form of an absolute obligation which is to become void in case of the non-occurrence of the contingency upon which the obligation is made to depend. ${ }^{\circ}$

As far as the writer is aware no one has ever called attention to this similarity of pattern between the mortgage and the conditional bond. Yet it is exactly this similarity which has led the writer to what he believes to be the clue to the whole situation. For, upon investigation, it appears that not only is the conditional bond, in the form in which it has come down to us, similar in pattern to the mortgage, but that its course of development has also been the same as that of the mortgage.

The writer believes that both of these legal devices were introduced by the Jews who, during the 12th and a good part of the r $3^{\text {th }}$ centuries, occupied in England the position of principal financiers and money-lenders, ${ }^{7}$ and that these devices were adopted and copied by Englishmen when they learned the business of money-lending from the Jew.

For many centuries before their settlement in England the Jews had cultivated the study of the law with great devotion and religious fervor. "Dine mamonoth," i. e. that branch of the law which deals with matters relating to property, contracts and torts, as distinguished from ritual law, was particularly favored by men of acute intellect among them. "He who wishes to acquire wisdom should study dine mamonoth," says an early Talmudic text. ${ }^{8}$ Throughout the lands of their dispersion justice was administered among them by rabbinical courts in accordance with Talmudic law, as interpreted by the leading rabbis. $^{\circ}$ As a result of those centuries of study and practice there developed among them a body of law, and with it a large number of legal forms and devices, far more mature and complex than anything that was known to English lawyers of the I2th century. Under these circumstances it would be very strange indeed if we did not find the Jews in England using, in their transactions with their Christian

\footnotetext{
6. See $2 \mathrm{Br}$. CoMm. *340.

7. See I Pollock and Maitland, op. cit. supra note I, 469 .

8. Baba Bathra, fol. 175b. 6-7.

9. See Finkelstein, Jewish Self-Governasent in The Midde Ages (1924)
} 
neighbors, the devices with which they were familiar, and which were elaborately discussed in their legal literature.

That so little attention has been given to the possible influence of the Jews upon the development of security devices in England, a field in which their influence should have made itself felt more than in any other branch of the law, is probably due to the fact that most of the sources of Jewish law are not available in English, and even where available it takes years of study to master their intricacies.

Pollock and Maitland, in discussing the possible influence of the Jews upon the development of English law, have this to say:

"Whether the sojourn of the Jews in England left any permanent mark upon the body of our law is a question that we dare not debate, though we may raise it. We can hardly suppose that from the Lex Judaica, the Hebrew law which the Jews administered among themselves, anything passed into the code of the contemptuous Christians. But that the international Lex Judaismi perished in 1290 without leaving any memorial of itself is by no means certain." 10

While it may be conceded that cases of deliberate and conscious adoption by English lawyers of rules and doctrines from Hebrew law were rare, although this is by no means certain, the adoption of security devices is an entirely different matter. The origin of these devices is extrajudicial; they are born of the exigencies of trade and commerce, where Jew meets Gentile on more or less equal terms, and where religious prejudices are shoved into the background. The judiciary only passes upon their effect and validity, and is only in a limited sense a party to their creation.

In order to trace the origin of the two devices under discussion it will be necessary for the writer to make a little excursus into Talmudic law. There is in Talmudic law a certain doctrine, very vaguely stated, which has given rise to a whole literature in post-Talmudic Hebrew lore. This doctrine is known as "asmakhta" and relates to conditional conveyances and obligations. In a terse phrase, characteristic of the Talmud, the rule is laid down that "asmakhta" is not valid. But what "asmakhta" is, that is, wherein its flaw consists, is a matter of lively dispute among post-Talmudic Hebrew authorities. Various theories have been offered as to the nature of "asmakhta," and as to the reason for its ineffectiveness. These will be discussed later. But in order to introduce the reader to the subject several concrete cases

10. I Pollock and Maitland, op. cit. supra note 1 , at 475. 
in which the doctrine is said to be applicable will be cited here from the Talmud.

$A$ and $B$ enter into a purchase and sale agreement, and $A$, the buyer, hands $B$, the seller, earnest money. They stipulate that in case of a breach by $A$ his earnest money shall be forfeited, and in case of a breach by $B$ he is to return to $A$ double the amount of the earnest money. Rabbi Jose says: the agreement is binding. Rabbi Judah says: the agreement is not binding. Such is the substance of an early text, quoted in the Babylonian Talmud. In discussing this text the Talmud classifies the transaction as an "asmakhta," and says that Rabbi Jose holds that "asmakhta" is valid, while Rabbi Judah holds that it is not valid. ${ }^{11}$

$A$ loans money to $B$ on the security of a field, and $A$ says to $B$ : "If you do not repay the loan within 3 years, the field shall be mine." The field is $A$ 's, if the loan is not repaid within the time agreed upon. This, again, is the substance of an early text, which is followed by an elaborate discussion in the Babylonian Talmud. ${ }^{12}$ The conclusion of the Talmud is that B's stipulation, upon its face, is an "asmakhta," and that therefore it ought not to be binding. In order to reconcile this text with their view of "asmakhta" the Talmudists assert that the text has reference to a case where $B$ said to $A$ "kni meakhshav," that is, acquire from now. As to the exact meaning of the cryptic phrase "kni meakhshav" opinions vary among post-Talmudic authorities. Rashi, the famous IIth century commentator of the Talmud, holds that the phrase means an actual present sale of the property with an option to repurchase, while others hold that the mere inclusion of the phrase "from now" in the forfeiture formula saves the transaction from the infirmity of "asmakhta."

$A$, the owner of a field, leased the field to $B$ under a cropsharing agreement, and $B$ let the field lie fallow. $B$ must pay to $A$ the value of his share of the crops which the field would have produced had it been cultivated. To this the Talmud adds that if $B$ had stipulated to pay a thousand "zuz" in case of his failure to cultivate, and that is an amount in excess of the actual loss to $A$, the stipulation would not have been binding because of "asmakhta." 18

$A$ paid part of a debt he owed to $B$. They deposited the bond with a third party under an agreement by the terms of which the third party was to return the bond to $B$, enabling him to recover the full amount named therein, if $A$ should fail to pay the balance of the debt

II. Baba Metzia, fol. $48 \mathrm{~b}$.

12. Id. at fol. $65 \mathrm{~b}$ et seq.

13. Id. at fol. 104a-104b. 
within a specified time. Rabbi Jose says: the agrecment is valid. Rabbi Judah says: it is not valid. Here again the reason given by the Talmud for Rabbi Judah's holding is "asmakhta." 14

Finally, $A$ deposited with the court the documents upon which his case rested, agreeing that if he did not appear again within a certain time, these should be null and void. This agreement is binding. although it is an "asmakhta," but only when made before a prominent court, and where $A$ 's failure to appear is not due to unavoidable circumstances. ${ }^{15}$ It should be added here that there is an important body of opinion holding that the rule in-this case is one of procedure, and that it applies only to stipulations made in court in connection with the conduct of a trial. ${ }^{16}$

These are the main cases, dealing with "asmakhta," which are mentioned in the Talmud. Among post-Talmudic Hebrew authorities two major trends of thought are discernible with regard to this doctrine. One, represented by Rav Hai Gaon ${ }^{17}$ and Maimonides, ${ }^{18}$ is that the flaw of "asnakhta" consists in the futurity of the conveyance or of the emergence of the obligation. According to these authorities a conveyance or an obligation in order to be valid must take effect immediately upon the performance of the act in law which is to give rise to it. If a conveyance is made or an obligation assumed to take effect in the future upon the happening of a contingency which is to occur after the act in law is performed, the conveyance or the obligation is not valid. In other words, a conditional transaction is valid only when the condition is subsequent, and not when it is precedent.

The other trend of thought, represented by Rashi, ${ }^{10} \mathrm{Ri}^{20}$ and Rabbi Solomon ben Adreth," is that the flaw of "asmakhta" consists

14. Baba Bathra, fol. 1682 .

15. Nedarim, fol. 27a-2;b.

16. Rif (Rabbi Isaac Alfassi) on Baba Bathra, ch. 10.

17. Mlckach Umemkar, ch. 17 (Vienna, 1810).

18. Yad Hachazakah (Code of Hebrew Law), Mekhirah, ch. 11, sec. 18.

19. Commentary on Baba Metzia, $48 \mathrm{~b}$, s. v. Asmakhta kanya.

20. Tosaphoth on Baba Mfetzia, 66a, s. v. Uminyomi.

21. Responsa of Rabbi Solomon ben Adreth, No. 933 (Lemberg, 1811). This theory of the nature of "asmakhta" finds confirmation in the light of modern research, which has revealed that throughout the ancient Orient penalty clauses were generally incorporated in agreements of every kind and description. See BLAU, MosatSSCHRIFT FÜR DIE W ISSENSCHAFT DES JUDENTUMS, vol. 69, p. 139 f. Blau was first to call attention to the connection between the doctrine of "asmakhta" and the penalty clauses in Assyro-Babylonian deeds. But his assertion that the doctrine is confined to the Babylonian Talmud, and that it was unknown among the Jews of Palestine is obviously incorrect, since it is definitely mentioned in the Palestinian Talmud under the name "izzumim". See Liebermas, Greek iN Jewish PAlestixe (1942) 4, and authorities there cited. See also Palestinian Talmud, Baba Bathra, c. 10, sec. 5.

Yiewed in this light the cryptic statement in the Babylonian Talmud, Baba Metzia, fol. $66 \mathrm{~b}$, that "every if is not valid" becomes intelligible. The word "if" in this statement 
in the fact that the conveyance is made, or the obligation assumed, as a penalty for the non-compliance with an undertaking to which it is collateral. There is lacking, according to these authorities, that finality of determination which is requisite for the validity of an act in law, since the intention of the party purporting to make the conveyance, or to assume the obligation, is to fulfill his main undertaking, and not to effect a transfer of his property, or an assumption of an obligation, other than his main obligation. In the case of a mortgage with a forfeiture clause, for example, the intention of the mortgagor is to undertake to pay the mortgage debt, and not to effect a conveyance of his property. The forfeiture clause is intended as a penalty for the nonpayment of the debt, and therefore it is not valid. Only where there is a present sale of the property with an option of repurchase is the transaction valid. The test for distinguishing between a true conditional sale and a mortgage is, accor $\ddot{\because} \cdot g$ to Rashi, ${ }^{22}$ the existence of a debt. If the party receiving the moncy is bound to repay it, at the option of the party parting with it, even after the time. fixed by the agrecment has expired, so that the risk of destruction and depreciation of the property falls upon the former, the transaction is a mortgage, and not a conveyance. But where the repaynent of the moncy is optional with the party receiving it, and the party parting with it hears the risk of loss and depreciation, the transaction is a true conditional sale. Such, in broad outline, is the doctrine of "asmakhta," as expounded by the leading authorities in I Hebrew law.

Let us now see how all this bears upon our problem of the origin of the English mortgage and the conditional bond. Maimonides in his Code of Hebrew Law ${ }^{23}$ cites the following device which was used by the "sages of Spain" for the purpose of removing the flaw of "asmakhta" from conditional obligations. The obligor would undertake an immediate and absolute obligation, and the obligee, on his part, would undertake to release the obligor upon the non-occurrence of the contingency upon which the obligation was to depend. The doctrine of "ashmakhta" not being applicable to releases and defeasances, this device accomplished the purpose of a conditional obligation in a legally valid manner by inverting the condition and attaching it to the release instead

is used as a tcrmus technicus, and the statement should be rendered in English as follows: "Every "if clause is not valid," that is every clause providing for a penalty, if the main undertaking is not fulfilled, is not valid. See Beth Joseph on Tur Choshen Mishpat, c. $207, \mathrm{sec}$. 18 , for a discussion of the difficulty involved in this statement when the word "if" is understood in its literal non-technical sense.

22. Commentary on Baba Metzia, 66b, s. v. Meakhshav kni.

23. Loc. cit. supra note 18. See Sma on Choshen Mishpat, ch. 207 , sec. 45 , where it is said that two separate undertakings, embodied in two separate instruments, are necessary in order to remove from the transaction all appearance of "asmakhta." 
of the obligation. This device, in a slightly different form, is also mentioned in a responsum by Rabbi Joseph Ibn Miggash, ${ }^{24}$ Maimonides' master.

From Maimonides' language it appears that the device described by him had been in common use among the Spanish Jews long before he wrote his code. Considering the leading position of the Spanish rabbis of the time among the Jews of Europe, it is quite likely that this device was adopted by the Jews of England and used by them in their dealings among themselves and with their Christian neighbors. Indeed, there is direct proof that this device was used by the Jews of England as early as the latter part of the I2th century. A deed, dated I 183 , recites that William of Tottenham acknowledges that he owes a hundred marks of silver to Avigaia, the Jewess of London and Abraham, her son, at Martinmas, for which he undertook to pay them $131 / 2$ per cent interest. If at Christmas following he pays them 40 marks, the remainder of the debt is to be reckoned at only 40 marks, on which he is to pay them 25 per cent. And if he fails to pay the 40 marks at Christmas, the debt is to remain a hundred marks. ${ }^{25}$ Apparently, the amount of money actually loaned was 80 marks, and the additional amount of 20 marks was intended as a penalty for nonpayment of the installment of 40 marks on the due date. This, it may readily be seen, is the Maimonides device, adapted to the special circumstances of the transaction. The essential characteristic of that device, namely that what is intended as a penalty for the non-performance of an undertaking appears as an absolute obligation with a condition subsequent, is obviously present in this transaction.

At a somewhat later period, in the middle of the $13^{\text {th }}$ century, we find reference to this device in the responsa of Rabbi Solomon ben Adreth, a leading authority of Barcelona, Spain. In one of these responsa ${ }^{26}$ he discusses a case in which 2 bonds of 1000 denarim each, were deposited, one by each of 2 parties, with a third party, to be delivered by the depositary to one of the parties in case of a breach of certain conditions by the other. The question was raised whether or not the transaction suffered from the flaw of "asmakhta." The rabbi decided that it was entirely free from "asmakhta," adding that such transactions were everyday occurrences, and that "the sages of past generations did not refrain from holding such transactions valid." In another responsum ${ }^{27}$ by the same rabbi we find a case in which an

24. Responsa of Rabbi Joseph Ibn Miggash, No. 97 (Warsav, 1870).

25. Round, Axcient Charters (Pipe Roll Society Publ. vi 10) 82.

26. Responsa of Rabbi Solomor ben Adreth swb nomine Toldoth Adam, No. 242.

27. Id. at No. 33 . 
instrument containing an absolute obligation, "without any condition or reservation," together with a release containing a condition, was delivered to a depositary, and again the question of "asmakhta" was raised with similar result. A case similar in all respects to the case first above cited from the responsa of Rabbi Solomon ben Adreth is also discussed in the responsa of Rabbi Asher ben Yechiel ${ }^{28}$ (r250I328) with like result. Here, too, the remark is made by the rabbi that "such transactions are everyday occurrences."

Turning to England again we find in the collection of Hebrew Shtaroth (deeds), ${ }^{29}$ published by the Jewish Historical Society of England, a Norwich document, dated $125 \mathrm{I}$ and embodying a transaction between two Jews, in which it is stated that a bond, together with a release, was delivered to a depositary, and that the depositary was to deliver both instruments to one of the parties in case the other failed to perform certain conditions.

In the 13th century this device was also used extensively by the Jews of England in their transactions with non-Jews. There are numerous entries on the rolls of The Exchequer of The Jews showing the use of this device. The following is a typical example: "Gilbert de Pelham attached to answer to William de $S$. in a plea of detention of a starr. The said William complains that whereas a starr, in which it was contained that if he paid to Abraham son of Ben', a Jew, at the feast of All Saints last past Io marks, then he should be quit of a debt of $\mathfrak{f}_{20}$ in which he was bound to the said Jew, was handed over, under his seal to Gilbert to be kept, the aforesaid Gillbert delivered it to the said Jew fraudulently and maliciously, to Williams' damage of f2o." 30 It is to be noted here that in this case, as in most others of this kind, the starr of acquittance was delivered to a third party, 'in equal hand,' a procedure which, as we have seen above, was characteristic of such transactions among the Jews as well as of the classical English mortgage in the earlier stage of its development.

28. Responsa of Rabbi Asher ben Yechiel, ch. 72, sec. 2.

29. Duvis, Hebrew DeEds (Shataroth) No. 22.

30. Calendar of The Plea Rolls of The Exchequer of The Jews, v. 3, p. 83 (1276). See also v. I, p. I49 (1268) -an acknowledgment by a Jewess that upon payment of 12 marks 2 chirographs, one of 20 marks and another of 2 marks, are to be quit ; pp. 162$163-a$ starr to the effect that upon payment of $28 \mathrm{~s}$ the debtor is to be quit of a chirograph in the sum of toos, was placed in "equal hand"; p. 168--"Defence, that it was agreed between them that if Henry should pay Diai I8s at the Purification of Blessed Mary in the 46th year, he should be quit of the chirograph of $40 s^{\prime \prime} ;$ p. 200-an 2Cknowledgment by a Jew that upon payment of $f 6$ a charter of $f 10$ is to be quit; $p p$. 300-30r-an agreement for the sale of timber: "And for the faithful performance of the said agreement, . * he, Michael, made the said Jew a charter for $\sum_{20}$ and caused it to be placed in the Cambridge Chirograph Chest, on condition, nevertheless, that if he, Michael, should deliver the said timber to the said Jew at the terms aforesaid, then he should be quit of the said charter of $£ 20$." For similar transactions see v. I, pp. 10, 58, 16r, 162-63, 189, 242, 306; v. 2, pp. 2, 4, 8, 30, 225, 293; v. 3, pp. $283-84,297-99$. 
As to transactions between non-Jews, we find in the $13^{\text {th }}$ century an occasional entry in the Close Rolls of a conditional obligation in the form of two separate instruments, a recognizance and a defeasance thereof. ${ }^{31}$ But alongside with these, and much more often, we find provisions for penalties, ${ }^{32}$ entirely undisguised, as well as provisions that in case of default the obligor is to pay to the obligee his damages and expenses, as to the amount of which the obligee is to be believed on his simple word or, sometimes, on hic oath. ${ }^{33}$ At the beginning of the 14 th century, ${ }^{34}$ however, the conditional obligation in the form of two separate instruments becomes more frequent, and by the middle of that century ${ }^{35}$ it becomes the regular, and, apparently, the only method of effecting a conditional obligation. As in the case of the conveyance with the condition subsequent, the conditional obligation continues for a long time to be incorporated in two separate instruments. The single instrument, containing both the obligation and the defeasance, makes its appearance only at the beginning of the ${ }_{1} j_{\text {th }}$ century, ${ }^{36}$

31. Alan grants to Joln the wardship of certain manors. Alan agrees that if John should be deprived of the wardship he would pay him $£_{50}$ for every year he is so deprived. In anuther instrument Joln grants that if he should be deprived of the "ardship, and Alan should pay him, "without plea or dispute," $£_{24}$, together with damages and expenses, he would release Alan of the remainder. Calendar of The Close Rolls, $1272-1279$, pp. 123-24 (1274).

32. $I d ., 1268-72$, pp. $292,557-58$.

33. Id. 1254-56, pp. 378-79; 1268-72, pp. 243, 292, 300, 410-11; 1272-79, pp. 254, 34. 355: il ainox, Forsetiare, No. 159 (1257). In an article on Evasions of The Liury Laws in The Middle Ages, to be published in The Hariard Theological Re. 2iiti, the writer has shown that this device, too, is of Hebrew origin. Professor Mlaitland was apparently unaware of the Ilebrew origin of this device. He thought it curious, and grouped it together with the device of making penal stipulations in favor of some charity, a device which, as will be shown in note 37 infra. also originated with the Jews, and which is of an entirely different nature than the damages and expenses device. In his article, $A$ Coniejance in the $13^{t / 2}$ Century (1\&ot) 7 L. Q. REv. 63, 68, Prof. Alaitland says: "Very curious too are the manifold devices by which the sin of usury is evarled, penal stipulations in favor of the relief of the Holy Land, or in favor of the building of 11 estminster Abbey, and agreements to accept the creditor's unsworn estimate of the 'damages and costs' that he has been put to by being kept rut of his money." Now, while it is true that the damages and costs device was user for the purpose of evading the usury laws, the same cannot be said of the stipulations in favor of some charity, since the creditor would never obtain the penalty stipulated for, it being payable, in most cases, to the King for the use of the charity.

34. Calendar of The Close Rolls, 1302-130\%, pp. 31\%, 450; 130;-13, p. 334; 1318-23, pp. 330. 343, 350, 715,724 .

35. $I d ., 1341-43$, pp. 244, 27j, 606; 1340-54, PP. 23R, 23n, 244-45, 246-47, 392, 405, 477, 4 is : 1354-אo. pp. 67, 70, 80.

36. The transition from two separate instruments to one single instrument may be scer in the volume of the Calendar of The Close Rolls covering the years 13991402. At page 4 in the transaction appcars in two separate entries, a recognizance and a condition. and at pascs 507.586, recognizance and condition appear in the same entry. The practice of incorporating the obligation and the defeasance in two separate instruments continued for some time, even after the single instrument became the usual form. No. IRI in MAmr. for example, which is dated 1433 , is a defeasance of a writing obligatory, made under the "Statute Merchant" to secure the performance of certain covenants in a marriagc contract. It is quite likely that during this transitional period the single instrument came to be known as the "single bond," and that this name clung to it for a long time after the two-instrument form became obsolete. This may well 
about the same time that the mortgage in the form of a conveyance with a condition subsequent begins to be incorporated in one single instrument.

The reason for the adoption by Englishmen of the two instrument device in the case of conditional obligations was the same as that which, as we have seen above, prompted the Jews to develop it, namely the rule against penalties. Whether dirctly influenced by the Hebrew doctrine of "asmakhta" or not, ${ }^{37}$ the rule against penalties

be the explanation of the term "single bond" in Act $\mathrm{I}$, Scene 3, of The Merchant of Venice. Pollock and Maitland interpret this term as meaning a bond without a condition or a penalty. In vol. 2 at $225, n .2$, they say: "Not one of the commentators, so far as we know, has rightly understood this term in the place where Shakespeare has made it classical. . . . Shylock first offers to take a bond without a penalty, and then adds, the fantastic penalty of the pound of flesh as a jesting afterthought." Why Shylock should have first offered to take a bond without any penalty at all, when the usual practice in those days was to name an amount equal to the amount of the principal obligation as a penalty in case of default, is not quite clear. It would scem therefore that the writer's explanation of the term is more in accord with the Shakespearean text. Shylock first offered to take the standard bond with the usual penalty, and then changed the penalty to a pound of flesh.

37. The influence of the Hebrew doctrine of "asmakhta" upon the development of the rule against penalties in English law may have been indirect. It may lave been exercised througli the devices which the Jews used in their transactions among themselves for the purpose of overcoming the difficulty of "asmaklita," and which were adopted by Englishmen. - In all of the available Hebrew documents, evidencing transactions between Jew and Jew in 13 th century England, there is not a single one in which provision is made for a penalty payable to the obligee. Instead, these documents contain provisions for penalties in favor of the King, the Queen, and, at least in one document, there is even a provision for a penalty payable to Earl Richard, the King's brother. See DAvis, Hebrew DezDS, Nos. 23, 54,65, 69, 87, 105, 128, 129 ; see also Calendar of The Plea Rolls of The Exchequer of The Jews, v. 2, p. 237, and v. 3 . pp. 3I, 53, 307. Occasionally, too, there is provision for a penalty payable to some clarity, such as a synagogue or a Jewish cemetery. DAvis, Nos. 47, 67. This device, like many others used in connection with writings obligatory, was apparently copied by Englishmen from the Jews. There are numerous instances of the usc of this device by Englishmen in the $13^{\text {th }}$ century. See $e$. g., Calendar of The Close Rolls, 1256-59, p. 493 ; 1259-6I, pp. 474-75; 1272-79, pp. 254, 343-344, 413 .

That this device originated with the Jews can hardly be doubted, for with them it filled a definite need, namely, that of overcoming the difficulty of the doctrine of "asmakhta," which rendered all penalties payable to the obligee invalid. The Jewish obligee, who could not have the full benefit of a penalty payable to himself, endeavored to have at least a provision which would serve to deter the obligor from defaulting. He therefore made the penalty payable to the King, who could be relied on to collect it, or to a charity to which the doctrine of "asmakhta" is not applicable. It should be borne in mind that this doctrine has nothing to do with the laws of usury. These laws deal with what is permissible and what is not, while the doctrine of "asmakhta" deals with what is valid and enforceable and what is not. Usury is a sin; a provision for a penalty, under Hebrew law, is not. It just is uneniorceable. The penalty ciause in the Hebrew documents cited in this note was thus designed to remedy a difficulty created by a doctrine which was peculiarly Hebrew in origin and development, and just as the difficulty was of the Jew's own making, so was the remedy. The provision for a penalty payable to the King is also found among the Jews of Spain at a much earlier time than the 13th century. In a Hebrew deed of conveyance, made at Leon, Spain, and dated 1053, there is a provision in the warranty clause to the effect that if the grantor fails to warrant, he is to pay Ioo denarim to the King. The French translation of this provision, given in 4 REvUE DES ETUDES JUIVES 227-229, where the document was first published, reads as follows: "Et si je suis empèché de repousser et rendre vaine une contestation et réclamation quelconque concernant cette vente, je payerai en cette ville la valeur de cette vigne sans aucun retard, et s'il avait retard, je payerai au roi cent deniers.". See also Sefer Hashtaroth (Formbook) of Rabbi Judah Barzillai (IIth century, Spain), form No. 72, where a similar provision is found. In 
in English law seems to have been first extensively invoked against Jewish creditors. In the Close Rolls of Henry III and Edw. I we find a number of cases in which royal equity is exercised in favor of Christian debtors, relieving them from "penalties and usuries" to Jewish creditors. 38 The terms "usuries" and "penalties" always go together in these royal mandates.

The Jewish creditor could not even always take shelter under the form of an absolute obligation with a conditional release. Form readily yielded to substance where the Jew was involved. Thus in the Close Rolls of Edw. I ${ }^{30}$ we find that by royal mandate to the Justices of the Jews the Convent of St. Mary is to be acquitted from "pains and usuries" to the Jews. In the same mandate the King orders the Justices to cause an inquest to be made as to how much money was received by the Convent from the Jews. Apparently, the penalties were disguised in the form of an absolute obligation, and the King ordered to disregard the form and ascertain the true amount of the loan. Some interesting entries bearing on this point are found in the Calendar of The Plea Rolls of The Exchequer of The Jews. "At the suit of Th. comes Deudoné Cryspin with Chirographs etc., to account, and demands of Th., by two charters which are in the King's treasury for his talliage, $\mathfrak{f}_{22}$ with $\mathfrak{f}_{20}$ interest. Defence, that the claim is unlawful, for that one of the charters was only by way of penalty, and is quit by the other, pursuant to a starr which is in the hands of J., clerk of the Chirograph chest of York." 10 In another case ${ }^{41}$ the Christian debtor alleged that the Jew, by his starr, granted that he, the debtor, be quit of a charter of $f_{4} 0$ upon payment of $f_{24} 4$ on or before a certain date, and of a charter for $\mathfrak{E}_{3} 0$ upon payment of $\mathfrak{E}_{15}$. And since the King granted that all penalties and usuries should cease, "he is not bound to answer touching the sum contained in the said charters which is, as it were, penalty."

this form there is also a provision that the payment of the peralty shall not discharge the obligor of his principal obligation. The last provision is also found in all of the above Hebrew documents from Angevin England, in which there is a penalty clause

Through the frequent use of this device by Englishmen the notion may have gradually gained ground among them that a provision for a penalty payable to the obligee is not valid, and that it savors of usury. The device may thus have preceded the rule among Englishmen, and may have contributed to its adoption by them. Some support for this supposition may be scen in the fact that for some time there seems to have been hesitation among Englishmen as to whether or not penalties were enforceable. Sce documents cited note 32 supra.

38. See Calendar of The Close Rolls, 1264-68, pp. 265-66, 305, 403; 1268-72, pp. $346,370,583-84$; 1272-79, pp. 170, 177, 271, 286.

39. Id., 1272-79, p. 177 .

40. Calendar of The Plea Rolls of The Exchequer of The Jews, v. 2, p. 295.

41. Id., v. 3, pp. 167-68. 
It thus appears that already during the reign of Henry III penalties were thought to be akin to usuries and to belong to the same class. It is true that for some time it was apparently thought that only penalties growing out of loan of money partook of the nature of usury, and that clauses providing for what we might call "liquidated damages" in case of breach, in contracts arising out of transactions other than a loan of money, did not come within the prohibition of usury. Thus we find during the reign of Edw. I a number of recognizances in the nature of liquidated damages in case of failure on the part of the obligor to perform certain undertakings, as, for example, in case the obligor fails to enfeoff the obligee of certain land, ${ }^{42}$ or in case the obligor's son, a minor, upon reaching maturity disaffirms his marriage to the obligee's daughter. ${ }^{48}$ However, towards the close of the same reign conveyancers seem to have begun to doubt the validity of such clauses, and the conditional obligation in the form of an absolute recognizance and a defeasance thereof begins to take the place of the provision for liquidated damages. By the middle of the I 4 th century, as we have seen above, this becomes the universal method of effecting a conditional obligation. ${ }^{14}$

It should be noted here that the employment of a third party, the "equal hand," as a depositary, is a prominent feature in the 14th century transactions between Christian and Christian, just as it is in the numerous $13^{\text {th }}$ century transactions between Jew and Jew and Jew and Christian. In a case decided in $13^{1} 3$ the headnote reads as follows:

"Debt, where the original bond was unconditional, and there was an indented conditioned penalty bond [un endenture condicionnel de couste], both of which were delivered to one $G$. The condition was satisfied and $G$ died. The bond came into the hands of his executors, one of whom was one of the parties to whom the bond was made; and because the defendant could not deny the unconditional bond the court gave judgment that the executor should recover the debt, though he had only obtained possession of the bond as executor, and notwithstanding the fact that the defendant had a bill of detinue claiming the same bond and others pending against him in the same eyre." 45

To return to the conveyance with the condition subsequent. The evidence is quite abundant that this device was used extensively by

42. Calendar of The Close Rolls, 1272-79, p. 430.

43. Id. at $4 \mathrm{I}$; see also Eyre of Kent, 6 \& 7 Edw. II, v. 2, p. 27.

44. See note 34 supra.

45. Eyre of Kent, 6 \& 7 Edw. II, จ. 2, p. 19. 
the Jews during the middle ages in exactly the same manner and for the same reason as the absolute obligation with the conditional release were used by them. Conveyance and defeasance were usually incorporated in two separate instruments and both instruments were delivered to a third party, to be returned to the nortgagor in case of payment of the debt on or before the due date, or turned over to the mortgagee in case of non-payment. A case involving two such documents is discussed in a responsum by Nachmanides. ${ }^{48}$ The two documents were delivered to a third party, to be held by him for a period of four years, the term of the mortgage. The argument was advanced by the mortgagor-grantor that the deed was not valid, since it represented an attempt to convey the property in futuro. This argument was dismissed by the rabbi on the ground that the deed effected an immediate conveyance, subject to defeasance within the time specified in the defeasance instrument, and was not a conveyance in futuro. Another case involving two such documents delivered to a third party, is discussed in a responsum of about the same time, written by Rabbi Solomon ben Adreth ${ }^{47}$ (1235-1310).

Earlier, in the 12 th century, an interesting question arose in connection with such conditional conveyances by way of security in a case decided by Rabbi Abraham ben David. ${ }^{48}$ In this case, as in the cases just cited, the deed of conveyance was delivered to a third party to be held by him during the term of the mortgage. Before the end of the term the grantec-mortgagce conveyed his interest in the property to another. When, after the expiration of the term, the mortgagee's grantee asserted his claim to the property, the mortgagor resisted this. clain, contending that the conveyance by the mortgagee was void. He supported his contention by the argument that at the time of the attempted conveyance the mortgagee had no interest in the property which he could validly convey, since his interest was not to become absolute before the term of the mortgage was over. The conveyance by the mortgagee, he argued, was in the nature of an attempted transfer of future acquisitions which, according to Hebrew law, is not valid. The rabbi decided in favor of the mortgagee's grantee, holding that

46. Responsa of Rabbi Solomon ben Adreth (Rashba), Attributed to Rabbi Moses ben Nachman (Ramban), No. II. This is a collection of responsa which were erroneously thought to have been written by Ramban. It was later discovered that their author, for the most part, was not Ramban, but Rashba. . There are, however, some responsa in this collection which were penned by the former, and the responsum cited in the text is one of them. Rashba himself in one of his signed responsa refers to this one as having emanated from Ramban. See Responsa of Rabbi Solomon ben Adreth, No.:916. (Lemberg, 1811).

47. Responsa of Rabbi Solomon ben Adreth sub nomine Toldoth Adam, No. I88; see also No. 209 for a similar case.

48. Cited in Tur, Choshen Mishpat, ch. 54 , sec. 13. 
at the time of the delivery of the deed to the third party the mortgagee acquired an immediate and present interest in the property, subject only to defeasance upon repayment by the mortgagor of the money advanced to him by the mortgagee within the period agreed on, and that therefore the conveyance by the mortgagee within that period was valid, although subject to the same defeasance.

Still earlier, in the I Ith century, the conditional conveyance by way of security is mentioned in the responsa of Rabbi Isaac Alfassi. ${ }^{40}$ Finally, it should be borne in mind that the doctrine of "asmakhta" is discussed in the Talmud in connection with a mortgage, and that the rule is laid down there that a forfeiture clause is not valid, and that only a present absolute conveyance with a provision for repurchase or defeasance is valid. So much for conditional conveyances by way of security used by the Jews in countries other than England.

As for England, the evidence is rather indirect, but no less convincing, nevertheless. In a 13 th century Hebrew document, ${ }^{50}$ evidencing a sale of a house by one Jew to another, we find the grantor making a representation under oath that he had made neither a deed of mortgage of the property, nor a deed of conveyance by way of security for a debt, previously to the conveyance attested by the document. Again, there are some entries on the Close Rolls ${ }^{51}$ to the effect that a charter of feoffnent was delivered by a Christian to the Chirographers to be kept in the "Jewish Chest". In these cases the charter was apparently delivered by way of security for a loan. Also, in a schedule of chattels which belonged to two deceased Jews, and which were found in the London Chest we find the following item: "Hamo and Ursell have ro charters of feoffment of land." 62 These charters, too, were apparently kept in the chest as security for loans. Finally, in the Mandate of The King Touching Lands and Fees of The Jews in Englasid, ${ }^{53}$ dated 1271, by which the Jews were deprived of the right of holding frceholds "in manors, lands, tenements, fees, rents or tenures of any kind whatsoever by charter, grant, feoffment, confirmation, or any other kind of obligation," it is stated that "touching lands and tenures, however, of which Jews were enfeoffed before the present statute and which they now hold, it is our pleasure that such infeudations be altogether annulled, and that those lands and tenements remain to the Christians who demised them to the Jews; so nevertheless that the Christians

49. No. 286 (Leghorn, 1781).

50. Davis, op. cit. supra note 37, No. 58 .

51. Calendar of The Close Rolls, 1247-51, p. 308; 1254-56, pp. 424-25.

52. V. I, p. 68 (1244).

Publ. LI-LIV. 
discharge what is due to the Jews on account of the money or chattels contained in their charters or chirographs, and given to them by the Jews for such grant of feoffment, without interest [sine usura]." The whole tenor of the above mandate or statute, and particularly the provision that the Christian grantors are to "discharge what is due to the Jews . . . without interest," clearly indicates that these transactions originated in loans, that the charters of feoffment were given to the Jews by way of security, and that they became absolute upon default by the Christian debtors. With regard to the above statute it might be added parenthetically that had the royal sense of justice been equally outraged at the oppression of the debtor class by the creditor class when the latter were Christians as when they were Jews, it might not have taken English courts several centuries before they evolved the doctrine of the equity of redemption.

To sum up. The conditional conveyance by way of security had been in use by the Jews for a long time prior to their settlement in England, and was used by them in England in their transactions with Christians. The technical device by which the conditional conveyance was effected was, in every detail, identical with the classical English mortgage in its original form, namely, two separate instruments were used and a third party was employed as a depositary. A device similar in conception and design to the conditional conveyance was used by the Jews during the middle ages in England and elsewhere for the purpose of effecting conditional obligations. This device, too, was in every respect identical with the common law conditional bond in the earlier stage of its development. Both of these devices were developed by the Jews for the purpose of evading a certain rule of Hebrew law which is similar to the rule against penalties in English law. The Jews introduced the business of money-lending on a large scale in England, and with it the means by which this business was carried on. When Englishmen learned the business of money-lending from the Jew they adopted his methods and devices, outstanding examples of which are the conditional conveyance by way of security and the conditional bond which have survived to our own day. 